\title{
A Unique Review Strategy that Motivates Student Learning
}

\author{
Donald L. Williams, EdD \\ Associate Professor of Biology \\ Park University
}

The use of educational games such as crossword puzzles, word search puzzles, modified television game shows, or commercial board and card games are attempts to make learning more fun and motivational regardless of the level of educational experience. This article explains how I have employed the melding of many of these games into one motivational and educational strategy. Students who faithfully availed themselves of the activities consistently improved their test scores and their overall grades within the course.

\section{The Problem}

I am the faculty person you other instructors resent-I will admit it. I am the one that over the years has provided my students with a study guide or review for the exam. Then, when they come to your exam, you hear that dreaded question, "Is there a study guide for this test, because my other professor gave us one?" I have justified the use of exam study guides because in the sciences, and especially for introductory students, the material can be as daunting as learning an entirely new language. Initially, the biggest problem was how to motivate the student to use the study guide as a valid means to improve understanding rather than simply as a means for guided cramming the night prior to the exam. I wanted my students to become really excited about and

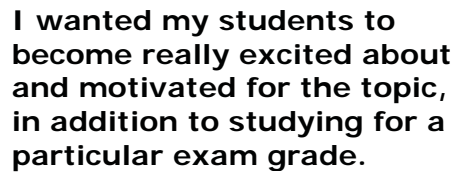

for a particular exam grade. If points were to be tied to the study guide, then I needed to grade its use; otherwise, most students would not have availed themselves of the guide and then would have complained about a difficult test or a low grade!

\section{Background}

Throughout my more than 35 years of teaching biology students, both at the secondary school and undergraduate levels, I have employed educational games, word puzzles, and commercially produced science board games to enhance student learning. Word puzzles, both those of my own making and those retrieved from text book ancillaries, have been used as review tools prior to exams. It was always believed, although never demonstrated statistically, that these actually improve student learning, as well as motivate students to better prepare and, generally to become more interested in the subject. Student exam scores appear on the whole to bear this out. More telling, in an anecdotal way, are the students' comments and obvious excitement when engaged in the challenge of the word puzzle, board game, or adapted television game show such as Jeopardy or Password.

A literature search into this area of word games and puzzles as motivation and review items reveals numerous articles in support of this educational method. A team of researchers in Australia report their fairly extensive review of the use of games and puzzles to stimulate class discussion of study topics. They conclude that “... the use of games and puzzles as a pedagogical tool is relatively common... Overall, first year biology students believe that the card game discussions and the crossword puzzles are useful aids to their learning and this finding encourages us to continue with their use, and develop more" (Franklin, Peat \& Lewis, 2003). In a study by Weisskireh (2006), the use of crossword puzzles as exam review tools 
garnered very favorable responses from students. Weisskireh reported that "Using a specially designed crossword puzzle provides an easy and engaging way for students to review concepts in preparation for a test." The narrative comments in the Results section of Weisskireh's article support his conclusions.

Other articles corroborated my suppositions, supporting in particular the use of such materials across the range of educational levels. Two examples report the use of modified television game shows such as Jeopardy (Rotter, 2004) and Family Feud (Glendon \& Ulrich, 2005) for a range of diverse learners, from mildly disabled students to nursing students, respectively. In another article, a board game was developed for pediatric medical students and residents to help them review and retain knowledge gained during third-year clinical clerkships and resident rotations (Ogershok \& Cottrell, 2004).

\section{A Strategy of Blending}

All of the foregoing simply provides foundation to my own use of educational games, not only as review items, but also as means to motivate my students. After years of using individual puzzles, games, exam review study guides, and even a simple "open door" policy for students to come to my office and spend time discussing review items, I discovered the use of a modified Bingo Game which employs a blending of many of the review items I had been using into one pedagogical tool. In the faculty development journal, The Teaching Professor, I discovered an article by $A$. J. Sutterluety, an instructor of exercise physiology at Baldwin-Wallace College in Ohio. "Bingo Game Decreases Procrastination, Increases Interaction With Content" (Sutterluety, 2002) was the perfect tool to allow me to meld a mélange of review items into one. Now, for each of my introductory courses, an option the student has to enhance learning is the use of a Biological Bingo Card.

\section{How It Works}

Figure 1 below displays an example of a card used for an introductory plant sciences course. Copies are printed on heavy grade stock paper. Students are informed that they are to keep the original during the entire semester. The rules for using the card are printed on the back of each card (Fig. 2). Duplicate pages of the card and the rules are also available on the instructor's Web site. Students are instructed of the rules at the start of the semester and usually a week prior to the first exam, as a reminder that items for the exam are due on the day of that test. On the test day, the Bingo Cards, together with any and all of the exam column's items, are turned in at the start of the exam. While the students are testing, I peruse their review items and stamp the card for each item verified as being complete and correct. A record is kept of the students' progress and points. Usually, I have the review items evaluated and points assessed by the end of the test for students to pick up and take with them. Figure 3 is a completed Bingo Card from an introductory biology course. Note my use of different rubber stamp images for different exams to verify that points have been assigned by me and not by a student trying to enhance their grade. 
Figure 1: Botany Extra Credit Bingo Card

\begin{tabular}{|c|c|c|c|c|}
\hline EXAM \# 1 & EXAM \# 2 & EXAM \# 3 & EXAM \#4 & EXAM \# 5 \\
\hline $\begin{array}{l}\text { Chs. } 1-3 \\
\text { Study Sheet } \\
\text { complete \& } \\
\text { correct }\end{array}$ & $\begin{array}{l}\text { Chs. } 4-7 \\
\text { Study Sheet } \\
\text { complete \& } \\
\text { correct }\end{array}$ & $\begin{array}{l}\text { Chs. 8-10 } \\
\text { Study Sheet } \\
\text { complete \& } \\
\text { correct }\end{array}$ & $\begin{array}{l}\text { Chs. } 11-17 \\
\text { Study Sheet } \\
\text { complete \& } \\
\text { correct }\end{array}$ & $\begin{array}{l}\text { Chs. } 18-24 \\
\text { Study Sheet } \\
\text { complete \& } \\
\text { correct }\end{array}$ \\
\hline $\begin{array}{l}\text { Create a } 10 \\
\text { pt. quiz with } \\
\text { correct } \\
\text { answers over } \\
\text { Exam \#1 } \\
\text { concepts }\end{array}$ & $\begin{array}{l}\text { Create a } 10 \\
\text { pt. quiz with } \\
\text { correct } \\
\text { answers over } \\
\text { Exam \#2 } \\
\text { concepts }\end{array}$ & $\begin{array}{l}\text { Create a } 10 \\
\text { pt. quiz with } \\
\text { correct } \\
\text { answers over } \\
\text { Exam \#3 } \\
\text { concepts }\end{array}$ & $\begin{array}{l}\text { Create a } 10 \\
\text { pt. quiz with } \\
\text { correct } \\
\text { answers over } \\
\text { Exam \#4 } \\
\text { concepts }\end{array}$ & $\begin{array}{l}\text { Create a } 10 \\
\text { pt. quiz with } \\
\text { correct } \\
\text { answers over } \\
\text { Exam \#5 } \\
\text { concepts }\end{array}$ \\
\hline $\begin{array}{l}\text { Create a } 20 \\
\text { word } \\
\text { crossword } \\
\text { puzzle }\end{array}$ & $\begin{array}{l}\text { Create a } 20 \\
\text { word word- } \\
\text { search puzzle }\end{array}$ & $\begin{array}{l}\text { Create a } 20 \\
\text { word } \\
\text { crossword } \\
\text { puzzle }\end{array}$ & $\begin{array}{l}\text { Create a } 20 \\
\text { word } \\
\text { crossword } \\
\text { puzzle }\end{array}$ & $\begin{array}{l}\text { Create a } 20 \\
\text { word word- } \\
\text { search puzzle }\end{array}$ \\
\hline $\begin{array}{l}\text { Find \& report } \\
\text { on a web site } \\
\text { dealing with } \\
\text { some concept } \\
\text { on Exam \#1 }\end{array}$ & $\begin{array}{l}\text { Find \& report } \\
\text { on a web site } \\
\text { dealing with } \\
\text { some concept } \\
\text { on Exam \#2 }\end{array}$ & $\begin{array}{l}\text { Find \& report } \\
\text { on a web site } \\
\text { dealing with } \\
\text { some concept } \\
\text { on Exam \#3 }\end{array}$ & $\begin{array}{l}\text { Find \& report } \\
\text { on a web site } \\
\text { dealing with } \\
\text { some concept } \\
\text { on Exam \#4 }\end{array}$ & $\begin{array}{l}\text { Find \& report } \\
\text { on a web site } \\
\text { dealing with } \\
\text { some concept } \\
\text { on Exam \#5 }\end{array}$ \\
\hline $\begin{array}{l}\text { Submit the } \\
\text { answers to } 2 \\
\text { review } \\
\text { questions from } \\
\text { each chapter } \\
\text { covered on } \\
\text { Exam \#1 }\end{array}$ & $\begin{array}{l}\text { Submit the } \\
\text { answers to } 2 \\
\text { review } \\
\text { questions } \\
\text { from each } \\
\text { chapter } \\
\text { covered on } \\
\text { Exam \#2 }\end{array}$ & $\begin{array}{l}\text { Submit the } \\
\text { answers to } 2 \\
\text { review } \\
\text { questions from } \\
\text { each chapter } \\
\text { covered on } \\
\text { Exam \#3 }\end{array}$ & $\begin{array}{l}\text { Submit the } \\
\text { answers to } 2 \\
\text { review } \\
\text { questions from } \\
\text { each chapter } \\
\text { covered on } \\
\text { Exam \#4 }\end{array}$ & $\begin{array}{l}\text { Submit the } \\
\text { answers to } 2 \\
\text { review } \\
\text { questions } \\
\text { from each } \\
\text { chapter } \\
\text { covered on } \\
\text { Exam \#5 }\end{array}$ \\
\hline
\end{tabular}

Note: Developed, with modifications, from "Bingo Game Decreases Procrastination, Increases Interaction With Content" printed in the November 2002 issue of The Teaching Professor (Sutterluety, 2002).

\section{Figure 2: Procedures and Rules}

- All documents must be word processed and checked for typos and spelling errors.

- All items for a given Exam (i.e., all items in one column) are to be turned in to the professor the day of the unit exam. No points will be available for those Exam items (Exam column) after the exam is given.

- All items submitted for extra credit will be checked during the exam and verified, via instructor's stamp, on the student's bingo card; therefore, the student must bring the card to class on the exam day to receive verification.

- Each crossword puzzle is to include a minimum of 20 terms from the unit studied, a blank puzzle with clues on one sheet, and a completed puzzle/answer page sheet. 
o (See http://puzzlemaker.school.discovery.com/CrissCrossSetupForm.html or some other web puzzle source such as http://search.teach-nology.com or build your own puzzle on graph paper.)

- Each word search puzzle is to include a minimum of 20 terms from the unit studied, an unsolved puzzle with words and definitions or clues for each word on a separate page and an answer page with words identified. (See: http://puzzlemaker.school.discovery.com/CrissCrossSetupForm.html or some other web puzzle source such as http://www.armoredpenguin.com or http://search.teachnology.com or build your own puzzle on graph paper.)

- Quizzes can be of any format the student chooses; correct answers are to be submitted with the quiz questions.

- Web site reports are to have a downloaded copy of the first page of the site and a one page critique of the site, i.e., what was the subject of the site, was it biologically correct, would you recommend it to others, etc. Write your report in two paragraphs, one as a summary of the site and the other as your opinions of its value, etc.

- Power Point presentation over a chosen topic can be either e-mailed to the professor as an attachment or can be copied onto a floppy disk and turned in to the professor by no later than the date given on the Bingo card.

- Disclaimer: The instructor has the right to reject any product that does not meet the quality expected from a college student-the student will be able to resubmit the item once for credit.

\section{Bingo Prizes}

- $\quad$ Each verified square $=2$ bonus pts. added at end of course.

- Complete row verified $=3$ additional pts. added at end of course.

- Complete exam column verified $=5$ pts. added to that exam's total.

Note: Developed, with modifications, from "Bingo Game Decreases Procrastination, Increases Interaction With Content" printed in the November 2002 issue of The Teaching Professor (Sutterluety, 2002).

Figure 3: Example Bingo Card

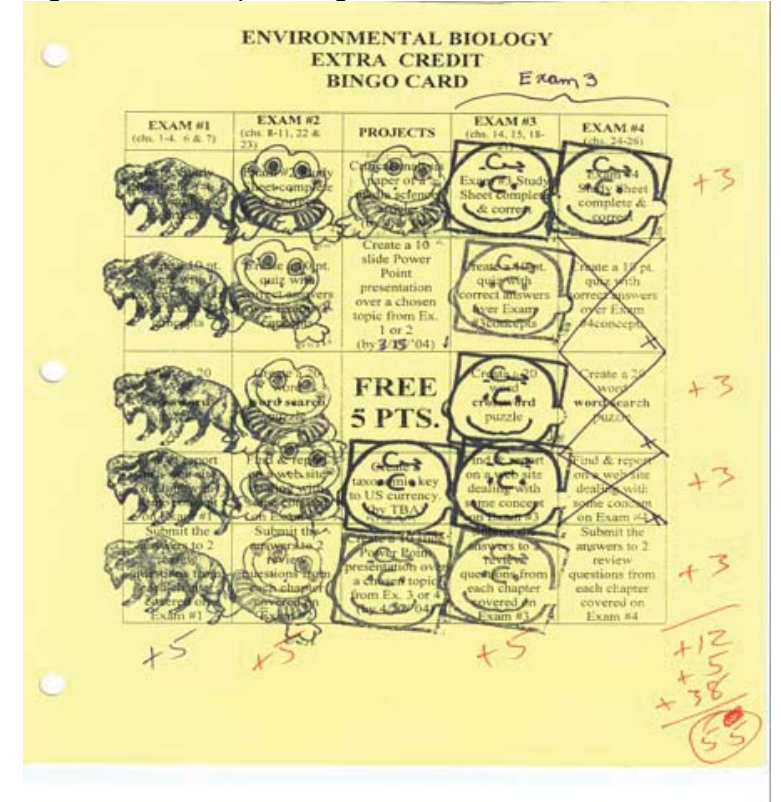

InSight: A Collection of Faculty Scholarship 


\section{Effectiveness}

What I have found while using the bingo card as a review technique is that students who faithfully avail themselves of the activities, consistently improve their test scores and their overall grade throughout the course. Many students choose not to use the activities in preparing for the first exam. After the first exam, however, many realize they may need some review help. When they try using some of the study items, they find their own understanding and test scores improving. The few bonus points assigned on completion of the items raise their overall grade as well, but not as much as the structured study does. In addition, I encourage students to collaborate on some of the items, particularly the exam study guides. This has led to student-organized and student-led study sessions. If, prior to the exam, students come to me concerning concepts or terms on the study guide ifficult for them to discern, I am more than willing to help, but most of the time, they can find these items via a thorough search through their text, notes, or laboratory activities.

\section{Conclusion}

I have always wanted my students to be successful; to that end, I provide some type of review instrument prior to major examinations. My use of educational games was intuitive at first, but research, as referenced above, bears out their effectiveness at all levels of education. The strategy of blending crossword puzzles, student-generated quizzes, and a variety of study guide items into one Bingo Game has worked quite well for me and my students. The bingo card provides

My use of educational games was intuitive at first, but research, as referenced above, bears out their effectiveness at all levels of education. several items from which to choose in order to enhance study and learning. From my standpoint, I have a convenient way to check students' material and provide them with a few bonus points. Additionally, the general format of the Biological Bingo Card is quite adaptable to any course situation, making the game both unique and successful as a motivational tool.

\section{References}

Franklin, S., Peat, M., \& Lewis, A. (2003). Non-traditional interventions to stimulate discussion: The use of games and puzzles. Journal of Biological Education. 37 (2), 79 - 84.

Glendon, K. \& Ulrich, D. (2005). Using games as a teaching strategy. Journal of Nursing Education 44 (7), 338339.

Ogershok, P.R., \& Cottrell, S. (2004). The pediatric board game. Medical Teacher 26 (6), 514 - 517.
Rotter, K. (2004). Modifying "J eopardy!" games to benefit all students. Teaching Exceptional Children. 36 (3), $58-62$.

Sutterluety, A. (2002). Bingo game decreases procrastination, increases interaction with content. The Teaching Professor. 16 (9), 4 5. Weisskirch, R. S. (2006). An analysis of instructor-created crossword puzzles for student review. College Teaching. 54 (1), 198 - 201. 
Williams has been a classroom teacher for more than 35 years dedicating the first three in a small western Kansas town where he taught all of the science in the middle and high school and coached three sports. Next, he taught for 15 more years at the high school level, teaching biology, health, and drivers training as well as coaching wrestling, all at another Kansas community. After earning a masters degree from Fort Hays State University, Hays, KS, he eventually moved to a small, private liberal arts college in central Kansas where he taught for 15 years. During that time he took a leave to complete his doctorate in education and conducted research on biological controls for crab grass at Ball State University, Muncie, IN. He has been teaching botany, health, and non major's biology on the Parkville campus for the last four years. He and his wife, Jan, who directs the Parkville campus Testing Center, enjoy reading, playing games, watching Pirate sports, traveling, and spending time with family and friends.

InSight: A Collection of Faculty Scholarship 